\title{
Developmental changes in pituitary-gonadal function in free-ranging lions (Panthera leo leo) of the Serengeti Plains and Ngorongoro Crater
}

\author{
J. L. Brown*, M. Bush $\dagger$, C. Packer $\ddagger$, A. E. Pusey $\ddagger$, S. L. Monfort $\dagger$, \\ S. J. O’Brien§, D. L. Janssen $\uparrow$ and D. E. Wildt $†$
}

* Department of Obstetrics and Gynecology, Uniformed Services University, Bethesda, MD 20814, USA; †National Zoological Park, Smithsonian Institution, Washington, DC 20008, USA;

$\ddagger$ Ecology and Behavioral Biology, University of Minnesota, Minneapolis, MN 55455, USA; $\S$ Laboratory of Viral Carcinogenesis, National Cancer Institute, Frederick, MD 21701, USA; and 7 Department of Veterinary Services, San Diego Zoological Society, San Diego, CA 92112, USA

Summary. Pituitary-gonadal function was examined in male lions free-ranging in the Serengeti Plains or geographically isolated in the Ngorongoro Crater of Tanzania. Lions were classified by age as adult ( $6 \cdot 1-9 \cdot 8$ years), young adult ( $3 \cdot 3-4 \cdot 5$ years) or prepubertal (1.4-1.6 years, Serengeti Plains only). Each animal was anaesthetized and then bled at 5 -min intervals for $100 \mathrm{~min}$ before and $140 \mathrm{~min}$ after i.v. administration of saline or $\mathrm{GnRH}(1 \mu \mathrm{g} / \mathrm{kg}$ body weight). Basal serum LH and FSH concentrations were similar $(P>0.05)$ among age classes and between locations. In Serengeti Plains lions, net LH peak concentrations after GnRH were $\sim 35 \%$ greater $(P<0.05)$ in prepubertal than in either adult or young adult animals. GnRH-stimulated LH release was similar $(P>0.05)$ between adult and young adult lions, and these responses were similar $(P>0.05)$ to those measured in Ngorongoro Crater lions. Basal and GnRH-stimulated testosterone secretion was higher $(P<0.05)$ in adult than in young adult lions and lowest $(P<0.05)$ in prepubertal lions. Age-class differences in testosterone production were related directly to the concentrations of $\mathrm{LH}$ receptors in the testis $(P<0.05)$. Basal and GnRH-stimulated testosterone secretion and gonadotrophin receptor concentrations within age classes were similar $(P>0.05)$ between lions of the Serengeti Plains and Ngorongoro Crater. Lower motility and higher percentages of structurally abnormal spermatozoa were observed in electroejaculates of young adult compared to adult Serengeti Plains males $(P<0.05)$ and were associated with decreased steroidogenic activity. In contrast, there were no age-related differences in ejaculate characteristics of Ngorongoro Crater lions. Seminal quality in the Crater population was poor in adult and young adult animals and was unrelated to alterations in pituitary or testicular function. In summary, only seminal quality in adult male lions was affected by location, whereas age significantly affected both basal and GnRH-stimulated testosterone secretion and seminal quality (Serengeti Plains only) in sexually mature males. The striking seminal/ endocrine differences among pride (breeding) males of different ages raises questions about the impact of age on individual reproductive performance in this species.

Keywords: lion; GnRH; LH; testosterone; receptors; testis; spermatozoa

\section{Introduction}

Members of the Family Felidae are generally solitary in nature. The exception is the lion (Panthera $l e o$ ) which has a highly structured social system (Schaller, 1972; Packer et al., 1988). Lion prides 
consist of permanent groups of 1-18 genetically-related adult females, dependant offspring and a coalition of 1-9 adult males. Females remain within their natal pride while young males are usually expelled as a group before reaching sexual maturity ( $\sim 3$ years of age) and all males leave eventually. These nomadic males form coalitions and attempt to gain and then retain possession of a pride until they move on or are ousted by another coalition of males (Schaller, 1972; Bertram, 1975; Pusey \& Packer, 1987; Packer et al., 1988) The primary determinant of a male's reproductive success is apparently the size of his coalition. Specifically, male lions in larger coalitions ( 3 or more males) gain tenure of female prides more easily, retain tenure longer, mate with more females and produce more surviving offspring than do singleton and paired males (Bygott et al., 1979). Male reproductive success does not appear to be related to social status, as lions do not form the dominance hierarchies typically observed in other social species (Schaller, 1972; Bertram, 1975; Packer et al., 1988). The influence of other factors including age and environment on reproductive performance in the lion has not been examined.

Demographic and behavioural data have been collected on the lions of the Serengeti ecosystem in Tanzania for more than 20 years (Schaller, 1972; Bertram, 1975; Bygott et al., 1979; Packer et al., 1988), but very little is known about the reproductive physiology of this species. Wildt et al. (1987) compared ejaculate quality in outbred lions free-ranging in the Serengeti Plains with two groups of animals known to have experienced population bottlenecks and reductions in genetic variability (O'Brien et al., 1987). These inbred groups consisted of an African population physically isolated within the Ngorongoro Crater (also in the Serengeti ecosystem) and a remnant population of Asiatic lions in western India. In that study, there was a direct relationship between the loss of genetic variability and the number of structurally abnormal spermatozoa measured in electroejaculates. Additionally, although only a few blood samples were collected before, during and after electroejaculation, there was evidence that circulating testosterone was lower in the Ngorongoro Crater and Asian lion populations compared to the males of the Serengeti Plains. This led to the speculation that perhaps the poor ejaculate quality and reduced steroidogenic activity in the inbred lions was due to a dysfunction at the pituitary or testicular level. The present study was therefore designed to extend these earlier observations by comparing ejaculate quality and the pituitarytesticular response to GnRH in genetically variable (Sergengeti Plains) and relatively less variable (Ngorongoro Crater) male lions. Because the age of each animal was known, this study afforded the unique opportunity to examine the possible impact of age on reproductive characteristics of a free-living species. Of particular interest was the examination of reproductive differences between mature and young adult lions, two age-classes of males which compete intensely for access to pride females.

\section{Materials and Methods}

Animals and treatment. Observational data have been collected for 2 prides in the Serengeti Plains since 1966 (Schaller, 1972; Bertram, 1975) and for an additional 21 prides in the Serengeti Plains and Ngorongoro Crater since 1974 (Bygott et al., 1979; Packer et al., 1988). All males evaluated in this study were associated with these prides, were of known age and could be identified individually by facial and ear scars, whisker patterns and natural markings or colourations (Pennycuick \& Rudnai, 1970). Sixteen adult and 6 prepubertal males from the Serengeti Plains and 12 adult males from the Ngorongoro Crater were examined in October and November. Male lions reach sexual maturity at 2.5-3 years of age (Schaller, 1972; Bertram, 1975; Packer et al., 1988) and reproduction apparently is not influenced by season (Schaller, 1972; Bertram, 1975). Animals were grouped into 3 age classes: (1) adult lions ranging from $6 \cdot 1$ to 9.8 years of age (mean, $7 \cdot 6 \pm 0.3$ years; $N=10$ in the Serengeti Plains, 6 in the Ngorongoro Crater); (2) young adults ranging from 3.3 to 4.5 years of age $(3.9 \pm 0.2$ years; $N=6,6)$; and (3) prepubertal males ranging from 1.4 to 1.6 years of age ( $1.5 \pm 0.1$ years; $N=6$, Serengeti Plains only). Because of permit restrictions, prepubertal males were not available in the Crater. There was no location difference $(P>0.05)$ in mean age between adult and young adult lion populations. All adult lions in the Serengeti Plains and Ngorongoro Crater were resident males of established prides. Of the young adult males, 5 of 6 and 4 of 6 were pride males in the Serengeti Plains and Ngorongoro Crater, respectively. The remaining young adult males were considered nomads.

All animals were located by a land vehicle and anaesthetized with Telazol (tiletamine- $\mathrm{HCl}+$ zolazepam- $\mathrm{HCl}$; Warner Lambert, Ann Arbor, MI, USA; 500-600 mg) delivered via a projectile dart (Wildt et al., 1987). Because 
animals were conditioned to being approached by the darting vehicle, most males appeared minimally disturbed before or during the darting procedure. In general, 3-6 males were darted consecutively, usually within a 5-10 min interval, which allowed the coalition of pride males to be physically kept together and facilitated serial blood sampling. Catheters (16-gauge, 5-cm, with obturator; Beckton-Dickinson, Rutherford, NJ, USA) were placed in a jugular, saphenous or lateral coccygeal vein, and blood samples $(5-10 \mathrm{ml})$ were collected at 5 -min intervals for $4 \mathrm{~h}$. Time between darting and sampling onset averaged $34 \pm 5 \mathrm{~min}$. A light surgical plane of anaesthesia was maintained with supplementary Telazol injections (100-250 mg i.m. or i.v.). Animals were assigned at random within age class and treated (i.v.) with saline $(0.154 \mathrm{M}-\mathrm{NaCl}, \mathrm{pH} 6.9 ; 4 \mathrm{ml})$ or $\mathrm{GnRH}(\mathrm{l} \mu \mathrm{g} / \mathrm{kg}$ body weight; Gonadorelin, Abbott Labs, Chicago, IL, USA) administered via the cannula after $100 \mathrm{~min}$ of sampling. In the Serengeti Plains, GnRH was administered to 7 of 10,4 of 6 and 3 of 6 adult, young adult and prepubertal animals, respectively. In the Ngorongoro Crater, 4 of 6 adult and 4 of 6 young adult animals received GnRH. The remaining animals were treated with saline. The weight of each animal was estimated using a regression equation for the calculation of body weight from chest girth $[y=1 \cdot 84 x-189 \cdot 11$; where $y=$ body weight $(\mathrm{kg})$ and $x=$ chest girth $(\mathrm{cm})]$ (U. S. Seal, personal communication). Adult and young adult lions in the Serengeti Plains weighed $168 \pm 4$ and $182 \pm 4 \mathrm{~kg}$, respectively. Adult and young adults in the Ngorongoro Crater weighed $200 \pm 7$ and $212 \pm 7 \mathrm{~kg}$, respectively. The comparatively larger size of the latter population probably reflects the availability of more plentiful prey in the Crater (Packer et al., 1988). Body weight of the prepubertal males averaged $88 \cdot 2 \pm 8 \cdot 6 \mathrm{~kg}$.

Semen collection and evaluation. Semen collection began immediately after the last blood sample using a standardized electroejaculation regimen (Wildt et al., 1983, 1984) with an electrostimulator (P-T Electronics, Boring, OR, USA) and $4 \cdot 6-\mathrm{cm}$ diameter rectal probe. The regimented sequence consisted of 80 incremental stimuli given in 3 series. Series I and II consisted of 30 stimuli each, divided into 3 sets of 10 stimuli at 4,5 and $6 \mathrm{~V}$ (Series I) and 5,6 and $7 \mathrm{~V}$ (Series II). In Series III, 20 stimuli, 10 each at 6 and 7 V, were administered. Semen from each series was pooled and evaluated for sperm concentration, percentage motility and progressive status (speed of forward progression based on a scale of $0=$ no movement, to $5=$ rapid forward movement) using techniques detailed previously (Wildt et al., 1983; Brown et al., 1989). Gross morphological assessments were made by fixing a $100 \mu l$ sample in $1 \mathrm{ml}$ glutaraldehyde ( $1 \% \mathrm{v} / \mathrm{v}$ in saline) and later evaluating 300 spermatozoa/ejaculate using phase contrast microscopy ( $\times 1000$ under oil). Testis volume was estimated by measuring the length and width of each testis using Vernier calipers and then calculating the volume of a prolate sphere $\left(V=4 / 3 \pi \mathrm{ab}^{2}\right.$, where $\mathrm{a}$ is one-half the length and $\mathrm{b}$ is one-half of the width of the testis) (Harrison et al., 1977). The two values for each male were added together to provide a volume for the combined testes.

Following electroejaculation a testicular parenchyma sample was collected from 6 adult, 4 young adult and 3 prepubertal Serengeti Plains lions, and from 3 adult and 4 young adult Ngorongoro Crater lions using an incisional biopsy technique (Burke, 1986). Briefly, after the scrotal area was shaved and surgically prepared, a sterile scalpel blade was used to make an incision through the scrotum and tunica vaginalis. Pressure was applied gently to the sides of the testis, and a $1-\mathrm{cm}$ incision was made through the tunica albuginea causing testicular parenchyma to bulge through the incised area. About $250 \mathrm{mg}$ parenchyma were removed, snap-frozen and stored in liquid nitrogen for subsequent analysis of LH and FSH receptors. Absorbable suture was used to close the tunica albuginea, tunica vaginalis and scrotal skin layers and the lions were given a prophylactic injection of a long-acting antibiotic.

Radioimmunoassays. Serum LH and FSH concentrations were quantified using specific radioimmunoassays previously validated for felid serum (Brown et al., 1988, 1989) using canine LH (LER-1685-1) and ovine FSH (NIHFSH-S8) as the reference standards. Assays were validated for lion serum by demonstrating recovery of mass and parallelism between serum pool dilutions and hormone standards. For the LH assay, 0.11, 0.22, 0.44, 1.05, 1.42 and $3.28 \mathrm{ng}$ were recovered after addition of $0 \cdot 1,0 \cdot 2,0 \cdot 4,0.8,1.6$ and $3.2 \mathrm{ng}$ canine $\mathrm{LH}$ and subtraction of endogenously measured hormone $(y=0.99 x+0.04 ; r=0.993)$. For the FSH assay, $2 \cdot 33,5 \cdot 25,10 \cdot 50,20 \cdot 22,39 \cdot 00$ and $80 \cdot 19 \mathrm{ng}$ were recovered after addition of $2 \cdot 5,5,10,20,40$ and $80 \mathrm{ng}$ ovine $\mathrm{FSH}$ and subtraction of endogenous ligand $(y=$ $0.99 x+0.08 ; r=0.999$ ). Assay sensitivities (defined as $90 \%$ of maximum binding) were 0.8 and $12 \mathrm{ng} / \mathrm{ml}$ for $100 \mu \mathrm{l}$ serum; inter- and intra-assay coefficients of variation were 11.6 and $4.9 \%$, and 7.6 and $4.5 \%$ for $\mathrm{LH}$ and FSH, respectively.

Serum testosterone was measured in unextracted serum using a ${ }^{125} \mathrm{I}$ radioimmunoassay kit (ICN, Carson, CA, USA) as described previously (Brown et al., 1989). Upon addition of $0.05,0.125,0.25,0.5,1.25$ and $2.5 \mathrm{ng}$ testosterone, and after subtraction of endogenous hormone, $0.08,0.15,0.25,0.49,1.45$ and $2.6 \mathrm{ng}$ were recovered $(y=$ $1.05 x+0.018 ; r=0.999)$. Assay sensitivity was $0.05 \mathrm{ng} / \mathrm{ml}$ for $50 \mu 1$ serum, and inter- and intra-assay coefficients of variation were $12 \cdot 0$ and $6.4 \%$, respectively.

Radioreceptor assays. Human chorionic gonadotrophin (9800 i.u./mg; Radio Systems Laboratories, Carson, CA, USA; hCG) and ovine FSH (LER-1976-A2) were used as labelled ligands, and hCG (3225 i.u./mg; Sigma, St Louis, MO, USA) and ovine FSH (NIADDK-oFSH-16) were used as unlabelled ligands in the LH and FSH assays, respectively. LH and FSH receptors were measured in crude testicular homogenates by a standard curve technique described previously for rat testis (Brown \& Chakraborty, 1988) using a pool of partly purified domestic cat testis membranes as the reference preparation. Biopsy samples were homogenized in $25 \mathrm{~mm}-\mathrm{Tris}-\mathrm{HCl}, 3 \cdot 8 \mathrm{~mm}-\mathrm{NaN}$, $10 \mathrm{~mm}-\mathrm{MgCl}_{2}, 0 \cdot 1 \% \mathrm{BSA}$ and $10 \%$ glycerol $\left(\mathrm{pH} 7.4\right.$ at $20^{\circ} \mathrm{C}$ ) to a concentration of $200 \mathrm{mg} / \mathrm{ml}$. Each standard curve was constructed by incubating 200000 c.p.m. labelled hormone (with or without excess unlabelled hormone for determination of non-specific binding) with 1.4-120 mg domestic cat testis membranes (fresh tissue equivalent)/tube. 
Triplicate $50-100 \mu \mathrm{l}$ samples of lion testis homogenate were analysed and compared to the standard curve. Assays were incubated for $16 \mathrm{~h}$ at $20^{\circ} \mathrm{C}$ and the reaction stopped by adding $3 \mathrm{ml}$ of cold rinse $(10 \mathrm{~mm}-\mathrm{Tris}-\mathrm{HCl}, 0 \cdot 154 \mathrm{M}$ $\mathrm{NaCl}, \mathrm{pH} 7.4$ at $4^{\circ} \mathrm{C}$ ) and centrifuging at $3500 \mathrm{~g}$ for $30 \mathrm{~min}$. Specific activities of the labelled hormones were $\sim 30$ and $5 \mu \mathrm{Ci} / \mu \mathrm{g}$ for hCG and oFSH, respectively, as determined by self-displacement analysis. For LH and FSH receptors, all tissues were analysed in one assay with intra-assay coefficients of variation of 8.9 and $7.6 \%$, respectively.

Pools of lion and domestic cat testis tissue were used to demonstrate hormone specificity and determine optimal assay $\mathrm{pH}$, incubation time and ion concentration using one-point saturation analysis. Scatchard analysis of saturation curves also was used to estimate binding affinities in tissue pools. Rat testes were analysed at the same times for comparative purposes.

Hormone iodinations. All hormones were iodinated using low concentrations of chloramine- $\mathrm{T}$ for increased retention of biological activity. Ovine $\mathrm{LH}$ and $\mathrm{oFSH}(5 \mu \mathrm{g})$ were iodinated with $1 \mathrm{mCi} \mathrm{Na}^{125} \mathrm{I}$ for $1 \mathrm{~min}$ using $2.5 \mu \mathrm{g}$ chloramine-T, and purified hCG $(5 \mu \mathrm{g})$ was iodinated for $4 \mathrm{~min}$ with $1 \mu \mathrm{g}$ chloramine-T. Sodium metabisulphite $(10 \mu \mathrm{g})$ was added to stop the iodination reaction. Labelled hormone was separated from free ${ }^{125} \mathrm{I}$ using anion exchange resin (AG 2-X8, 100-200 mesh, chloride form; BioRad Laboratories, Richmond, CA, USA). Columns $(1 \times 5 \mathrm{~cm})$ containing $3 \mathrm{ml}$ of resin equilibrated in $0.05 \mathrm{M}$-sodium phosphate buffer $\left(\mathrm{NaPO}_{4} ; \mathrm{pH} 7.6\right)$ were prepared by successive elution with $2 \cdot \mathrm{ml}$ samples of $0.5 \mathrm{M}-, 5 \% \mathrm{BSA}$ in $0.05 \mathrm{M}$ - and $0.05 \mathrm{M}-\mathrm{NaPO}_{4}$. The reaction mixture was layered onto the column and labelled hormone eluted with $2 \mathrm{ml} 0.05 \mathrm{M}-\mathrm{NaPO}_{4}$ into a tube containing $1 \mathrm{ml}$ phosphatebuffered saline with $0.1 \%$ gelatin.

Data analysis. Gonadotrophin responses to $\mathrm{GnRH}$ and testosterone responses to $\mathrm{LH}$ were evaluated as net peak height (greatest post-treatment concentration minus pretreatment level) and net area under the response curves as previously described (Brown et al., 1989). To stabilize the variance, all endocrine data were subjected to log transformation before analysis. The data were analysed utilizing Harvey's Mixed Model Least Squares and Maximum Likelihood computer program (Harvey, 1988), using a subclass model with location and age as the effects. Mean differences were determined using linear contrasts. Data are presented as arithmetic means \pm s.e.m.

Basal and pulsatile serum hormone patterns were evaluated as described by Brown et al. (1988).

\section{Results}

\section{Semen characteristics and testis size}

In Serengeti lions, ejaculate volume, sperm concentration and sperm progressive status did not vary $(P>0.05)$ between adult and young adult lions; however, adult males consistently produced ejaculates with a higher $(P<0.05)$ sperm motility rating and more morphologically normal spermatozoa $(P<0.05)$ than did young adult males (Table 1$)$. No spermatozoa were found in the electroejaculates of prepubertal animals. Compared to adult Serengeti lions, adult and young adult males from the Ngorongoro Crater produced ejaculates with a similar volume and sperm concentration but with a lower sperm percentage motility rating and overall higher rate of teratospermia $(P<0.05)$. The most prevalent sperm abnormalities involved midpiece and flagellum defects. Ejaculate quality among young adult lions of the Serengeti Plains and Ngorongoro Crater and adult males of the Ngorongoro Crater was similar with only a few exceptions, including an increased incidence of bent midpieces (without droplets) in young adult Plains males and coiled flagella in both groups of Crater males $(P<0.05)$.

Within location, combined testes volume was similar $(P>0.05)$ between adult and young adult males in the Serengeti Plains and Ngorongoro Crater, respectively (Table 1). Testes volume tended to be greater in Plains than Crater males, but was only significantly different $(P<0.05)$ between young adult Crater males and adult Plains males. Volume of prepubertal testes was only $25-30 \%$ of that found in adult and young adult lions.

\section{Serum LH and FSH profiles}

Basal concentrations of $\mathrm{LH}$ and FSH in saline-treated control animals were stable over time and unaffected $(P>0.05)$ by age or location (Table 2, Fig. 1a). Pulsatile LH secretion (1-3 pulses/ $4 \mathrm{~h}$ ) was observed in 2 of 5 adult and 2 of 4 young adult and all of the prepubertal control lions (Fig. 2). Pulse amplitudes (above baseline) were 2.0 to $5.5 \mathrm{ng} / \mathrm{ml}$ and averaged $3.6 \pm 0.7 \mathrm{ng} / \mathrm{ml}$. Pulsatile FSH secretion was not observed. Serum LH concentrations peaked within $15-25 \mathrm{~min}$ after 
Table 1. Electroejaculate traits of free-ranging lions from 2 geographic locations in the Serengeti ecosystem

\begin{tabular}{|c|c|c|c|c|c|}
\hline & \multicolumn{3}{|c|}{ Serengeti Plains } & \multicolumn{2}{|c|}{ Ngorongoro Crater } \\
\hline & Adult & Young adult & Prepubertal & Adult & Young adult \\
\hline Ejaculate volume (ml) & $6.0 \pm 0.9$ & $5.6 \pm 1.4$ & $0.8 \pm 0.2$ & $3 \cdot 4 \pm 1 \cdot 2$ & $5 \cdot 2 \pm 1 \cdot 5$ \\
\hline $\begin{array}{l}\text { Sperm concentration } / \mathrm{ml} \\
\left(\times 10^{-6}\right)\end{array}$ & $12 \cdot 3 \pm 3.8$ & $8 \cdot 0 \pm 4 \cdot 2$ & 二 & $11.8 \pm 8.0$ & $11.9 \pm 5.2$ \\
\hline Sperm motility (\%) & $89 \cdot 0 \pm 2 \cdot 1^{a}$ & $72 \cdot 0 \pm 5 \cdot 5^{b}$ & - & $59 \cdot 0 \pm 8 \cdot 0^{b}$ & $59 \cdot 0 \pm 10 \cdot 0^{\mathrm{b}}$ \\
\hline Sperm progressive status & $4 \cdot 1 \pm 0 \cdot 3$ & $3 \cdot 0 \pm 0 \cdot 2$ & - & $2.9 \pm 0.4$ & $2 \cdot 9 \pm 0.5$ \\
\hline Sperm normalities $(\%)$ & $71 \cdot 5 \pm 4 \cdot 8^{a}$ & $43.8 \pm 9 \cdot 1^{b}$ & - & $33.9 \pm 7.8^{b}$ & $33 \cdot 0 \pm 12 \cdot 1^{\mathrm{b}}$ \\
\hline \multicolumn{6}{|l|}{ Sperm abnormality type $(\%)$} \\
\hline Macrocephalic & $0.3 \pm 0 \cdot 1$ & $0.4 \pm 0.1$ & - & $0.4 \pm 0.2$ & $0.5 \pm 0.2$ \\
\hline Microcephalic & $0.1 \pm 0.1$ & $0.1 \pm 0.1$ & - & $0 \cdot 3 \pm 0.2$ & $1.4 \pm 0.6$ \\
\hline Bicephalic & $0 \cdot 2 \pm 0 \cdot 1$ & $0.3 \pm 0.2$ & - & $4.0 \pm 2.8$ & $0.2 \pm 0.2$ \\
\hline Abnormal acrosome & $0.8 \pm 0.4$ & 0 & - & $2.7 \pm 0.7$ & $1.4 \pm 0.5$ \\
\hline Bent neck & $1.2 \pm 0.6$ & $0.5 \pm 0.3$ & - & $2.0 \pm 0.3$ & $0.6 \pm 0.1$ \\
\hline Abnormal midpiece & $1.9 \pm 0.9$ & $1.5 \pm 0.4$ & - & $3.5 \pm 0.9$ & $2.7 \pm 0.9$ \\
\hline Bent midpiece & $3 \cdot 7 \pm 1 \cdot 3^{\mathrm{a}}$ & $12.8 \pm 3.6^{\mathrm{b}}$ & - & $5 \cdot 0 \pm 2 \cdot 2^{\mathrm{ab}}$ & $2 \cdot 3 \pm 0.4^{\mathrm{a}}$ \\
\hline Bent midpiece with droplet & $3 \cdot 8 \pm 1 \cdot 7^{a}$ & $24 \cdot 1 \pm 12 \cdot 9^{b}$ & - & $18 \cdot 9 \pm 4 \cdot 0^{6}$ & $24 \cdot 8 \pm 6 \cdot 6^{\mathrm{b}}$ \\
\hline Cytoplasmic droplet & $8.9 \pm 3.0$ & $5.0 \pm 2.9$ & - & $8.3 \pm \quad 1.9$ & $10 \cdot 6 \pm \quad 5 \cdot 0$ \\
\hline Biflagellate & $0 \cdot 1 \pm 0 \cdot 1$ & $0 \cdot 1 \pm 0 \cdot 1$ & - & $0.2 \pm 0.1$ & 0 \\
\hline Coiled flagellum & $5 \cdot 6 \pm 2 \cdot 1^{a}$ & $5 \cdot 3 \pm 2 \cdot 8^{a}$ & - & $12.0 \pm 3.4^{6}$ & $18 \cdot 9 \pm 8 \cdot 7^{b}$ \\
\hline Bent fiagellum & $2 \cdot 0 \pm 0 \cdot 6^{a}$ & $6 \cdot 2 \pm 1.5^{b}$ & - & $8 \cdot 4 \pm 3.7^{b}$ & $3.7 \pm 0.7^{\mathrm{ab}}$ \\
\hline Testes volume $\left(\mathrm{cm}^{3}\right)$ & $87 \cdot 8 \pm 6 \cdot 4^{a}$ & $80 \cdot 1 \pm 7 \cdot 3^{\mathrm{ab}}$ & $21 \cdot 2 \pm 1 \cdot 9^{c}$ & $69.8 \pm 14.9^{\mathrm{ab}}$ & $63 \cdot 1 \pm 7 \cdot 3^{b}$ \\
\hline
\end{tabular}

${ }_{\text {abc }}$ Values (mean \pm s.e.m.) within rows with different superscripts are different $(P<0.05)$.

GnRH treatment in all animals (Fig. la). In the Serengeti population, LH peak height was $\sim 35 \%$ greater $(P<0.05)$ in prepubertal compared to the adult and young adult males; peak height in the last two groups was similar $(P>0.05)$. LH peak height in adult and young adult lions in the Ngorongoro Crater was similar $(P>0.05)$ to that observed in the Serengeti Plains. Pituitary FSH response to GnRH was not influenced $(P>0.05)$ by age or location. Overall pre-treatment serum FSH concentrations averaged $29.3 \pm 0.2 \mathrm{ng} / \mathrm{ml}$. After GnRH treatment, FSH concentrations increased to $49.8 \pm 0.4 \mathrm{ng} / \mathrm{ml}$.

Table 2. Mean ( \pm s.e.m.) basal serum LH and FSH in free-ranging lions from 2 geographic locations in the Serengeti ecosystem

\begin{tabular}{lrcc}
\hline Group & No. & $\begin{array}{c}\text { Serum LH } \\
(\mathrm{ng} / \mathrm{ml})\end{array}$ & $\begin{array}{c}\text { Serum FSH } \\
(\mathrm{ng} / \mathrm{ml})\end{array}$ \\
\hline Serengeti Plains & & & \\
$\quad$ Prepubertal & 6 & $2 \cdot 8 \pm 0 \cdot 2$ & $28 \cdot 3 \pm 1 \cdot 8$ \\
$\quad$ Young adult & 6 & $3 \cdot 6 \pm 0 \cdot 4$ & $31 \cdot 6 \pm 3 \cdot 1$ \\
$\quad$ Adult & 10 & $3 \cdot 6 \pm 0 \cdot 4$ & $36 \cdot 5 \pm 3 \cdot 7$ \\
Ngorongoro Crater & & & \\
$\quad$ Young adult & 6 & $3 \cdot 4 \pm 0 \cdot 2$ & $34 \cdot 2 \pm 3 \cdot 1$ \\
$\quad$ Adult & 6 & $3 \cdot 0 \pm 0 \cdot 4$ & $29 \cdot 6 \pm 2 \cdot 9$ \\
\hline
\end{tabular}

\section{Serum testosterone profiles}

Basal concentrations of serum testosterone decreased $20-50 \%$ over time in $\sim 80 \%$ of the adult and young adult males (Fig. 1b). In the Serengeti population, overall mean concentration for the 


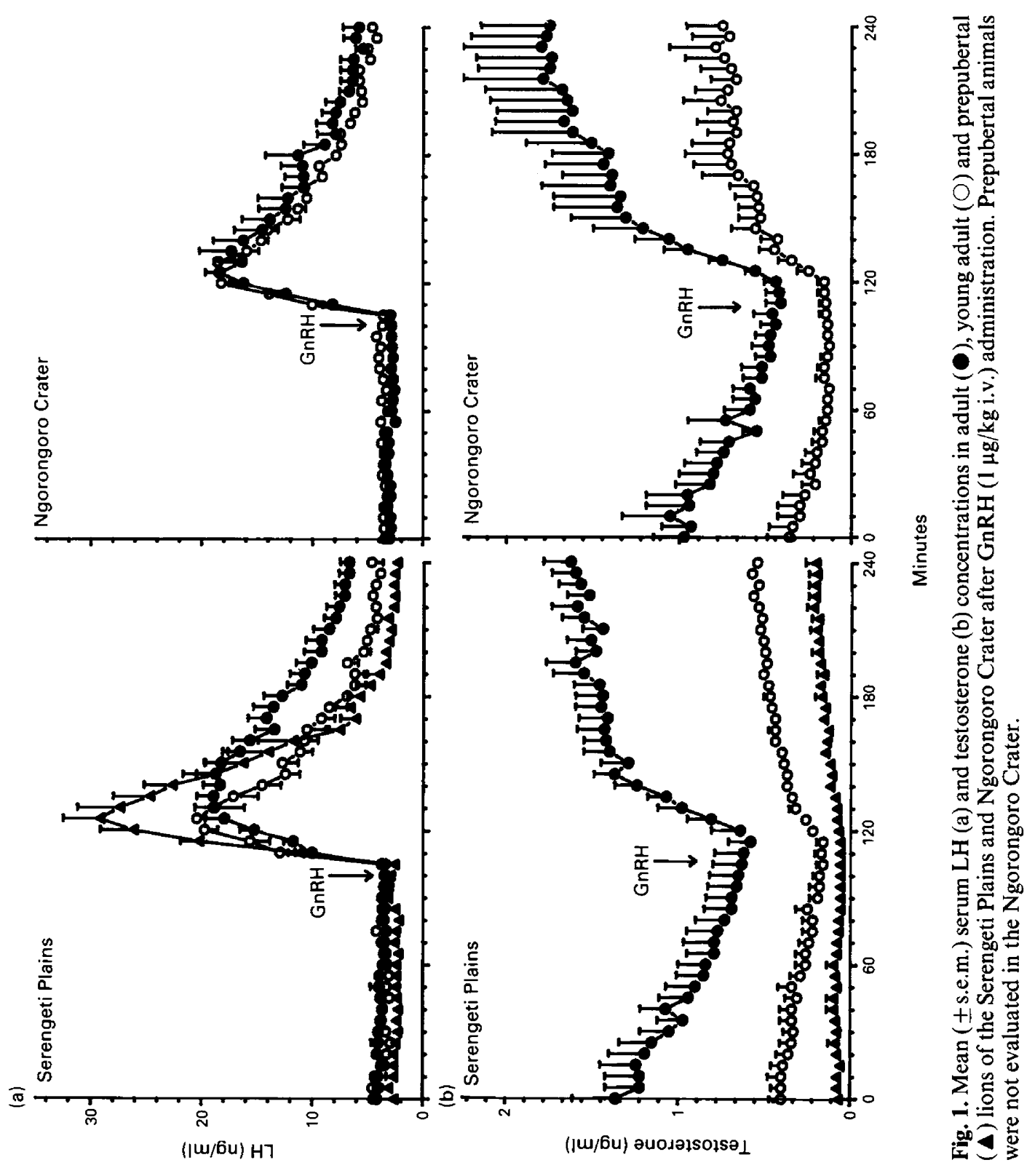


4-h bleeding period was greater $(P<0.05)$ in adult $(1.13 \pm 0.25 \mathrm{ng} / \mathrm{ml})$ than in young adult $(0.46 \pm 0.06 \mathrm{ng} / \mathrm{ml})$ animals, and these concentrations were, in turn, greater $(P<0.05)$ than those observed in the prepubertal animals $(0.12 \pm 0.02 \mathrm{ng} / \mathrm{ml})$. The overall pattern of testosterone secretion in the Ngorongoro Crater lions was similar $(P>0.05)$ to that observed in Serengeti Plains males; mean testosterone concentration was higher in adult $(0.96 \pm 0.36 \mathrm{ng} / \mathrm{ml})$ than in young adult $(0.35 \pm 0.06 \mathrm{ng} / \mathrm{ml})$ males.

Age differences also were observed in GnRH-stimulated testosterone secretion (Fig. Ib). For the Serengeti population, net peak heights and areas under the response curves were greater $(P<0.05)$ in adult $\left(1.30 \pm 0.14 \mathrm{ng} / \mathrm{ml}, 28.6 \pm 2.6 \mathrm{~cm}^{3}\right)$ than in young adult $(0.42 \pm 0.04 \mathrm{ng} / \mathrm{ml}$, $\left.10 \cdot 7 \pm 1.2 \mathrm{~cm}^{3}\right)$ lions. A similar relationship was observed between the adult $(1.44 \pm 0.47 \mathrm{ng} / \mathrm{ml}$, $\left.25.6 \pm 3.7 \mathrm{~cm}^{3}\right)$ and young adult $\left(0.70 \pm 0.24 \mathrm{ng} / \mathrm{ml}, 17.1 \pm 4.5 \mathrm{~cm}^{3}\right)$ lions of the Ngorongoro Crater. The lowest testosterone response to $\mathrm{GnRH}$ was observed in prepubertal males $(0 \cdot 16 \pm$ $\left.0.03 \mathrm{ng} / \mathrm{ml}, 4.4 \pm 0.8 \mathrm{~cm}^{3}\right)$. Within age class, there were no differences $(P>0.05)$ between Serengeti Plains and Ngorongoro Crater males in the testicular response to exogenous GnRH.

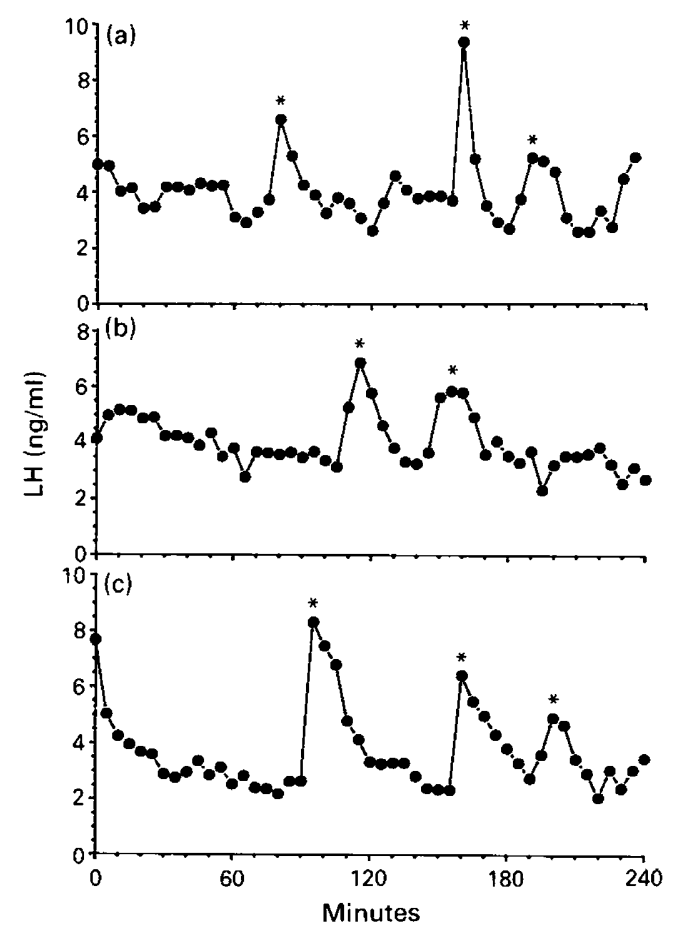

Fig. 2. LH pulses $\left(^{*}\right)$ during the 240 -min control bleeding period from an individual adult (a), young adult (b) and prepubertal (c) lion.

\section{Testicular LH and FSH receptors}

For each hormone (LH or FSH), assay conditions required for maximal gonadotrophin binding to testis homogenates were similar for domestic cat and lion tissue. For the $\mathrm{LH}$ receptor assay, binding of ${ }^{125} \mathrm{I}$-labelled hCG to testicular tissue was maximal following incubation for $12 \mathrm{~h}$ at $20^{\circ} \mathrm{C}$ and was stable through $24 \mathrm{~h}$ of incubation. The highest specific binding was observed in the presence of $1-20 \mathrm{mM}-\mathrm{MgCl}_{2}$ or $5-20 \mathrm{mM}-\mathrm{CaCl}_{2}$. Receptor binding in cat and lion testis was $\sim 50 \%$ 
Table 3. Mean ( \pm s.e.m.) concentrations of testicular LH and FSH receptors in free-ranging lions from 2 geographic locations in the Serengeti ecosystem

\begin{tabular}{lccc}
\hline Group & No. & $\begin{array}{c}\text { LH receptors } \\
\text { (fmol/mg tissue) }\end{array}$ & $\begin{array}{c}\text { FSH receptors } \\
\text { (fmol/mg tissue) }\end{array}$ \\
\hline $\begin{array}{l}\text { Serengeti Plains } \\
\quad \text { Prepubertal }\end{array}$ & 3 & $0.08 \pm 0 \cdot 02^{\mathrm{a}}$ & $10 \cdot 5 \pm 2 \cdot 3^{\mathrm{a}}$ \\
$\quad$ Young adult & 4 & $0 \cdot 24 \pm 0 \cdot 02^{\mathrm{b}}$ & $3.6 \pm 0 \cdot 4^{\mathrm{b}}$ \\
$\quad$ Adult & 6 & $0.66 \pm 0 \cdot 12^{\mathrm{c}}$ & $4 \cdot 7 \pm 0 \cdot 4^{\mathrm{b}}$ \\
$\begin{array}{l}\text { Ngorongoro Crater } \\
\quad \text { Young adult }\end{array}$ & 4 & $0 \cdot 18 \pm 0.07^{\mathrm{b}}$ & $5 \cdot 1 \pm 0 \cdot 5^{\mathrm{b}}$ \\
$\quad$ Adult & 3 & $0.68 \pm 0 \cdot 17^{\mathrm{c}}$ & $4 \cdot 6 \pm 0.5^{\mathrm{b}}$ \\
\hline
\end{tabular}

${ }^{\text {abc Values.(mean } \pm \text { s.e.m.) within columns with different superscripts are }}$ different $(P<0.05)$.

higher at $\mathrm{pH} 5.0$ compared to $\mathrm{pH} 7.4$, with no change in receptor affinity. This contrasts with rat data in which binding was similar for $\mathrm{pH}$ values between 5.0 and 8.0 (data not shown). For the analysis of lion receptors, all binding assays were performed at the more physiological $\mathrm{pH}$ of 7.4 as described previously (Ketelslegers et al., 1978; Sundby et al., 1984; Brown et al., 1988). Binding of ${ }^{125}$ I-labelled hCG to testis tissue was specific and could be displaced $>70 \%$ by $100 \mathrm{ng}$ unlabelled hCG, NIH-LH-S18 (oLH), NIH-LH-B10 (oLH) but not by oFSH, NIH-GH-1003A (bovine GH), NIH-P-S1I (sheep prolactin) or GnRH. Estimated binding affinity $\left(K_{\mathrm{d}}\right)$ was similar $(P>0.05)$ between pools of lion $\left(3.6 \pm 0.3 \times 10^{-11} \mathrm{M} ; \mathrm{N}=2\right)$ and domestic cat $\left(2.9 \pm 0.1 \times 10^{-11} \mathrm{M}\right.$; $\mathrm{N}=11$ ) testis homogenate.

Maximal binding of ${ }^{125} \mathrm{I}$-labelled oFSH to domestic cat and lion testicular tissue was observed after $12-14 \mathrm{~h}$ of incubation at $20^{\circ} \mathrm{C}$ in the presence of $5-20 \mathrm{mM}-\mathrm{MgCl}_{2}$ or $\mathrm{CaCl}_{2}$ and at a pH of $6 \cdot 8-7 \cdot 4$. These results were similar to those observed for rat tissue (data not shown). Binding was specific and displaced by oFSH and NIH-FSH-Bl but not by hCG, oLH, bovine GH, sheep prolactin or GnRH. Receptor $K_{\mathrm{d}}$ was similar $(P>0.05)$ between lion $\left(3.2 \pm 0.4 \times 10^{-10} \mathrm{M} ; \mathrm{N}=2\right)$ and domestic cat $\left(4.2 \pm 0.6 \times 10^{-10} \mathrm{M} ; \mathrm{N}=9\right)$ tissue.

For both the LH and FSH receptor assays, specific binding increased linearly with increasing concentration of tissue homogenate. Dilutions of lion testis homogenate paralleled the domestic cat testis receptor standard curve. Receptor concentrations obtained by Scatchard and standard curve analyses were in agreement $(r=0.89 ; P<0.01)$.

In the Serengeti animals, testicular $\mathrm{LH}$ receptor concentration in the prepubertal males was only $\sim 30 \%$ of that observed in young adult males, and the receptor binding in the latter animals was only $\sim 30 \%$ of that measured in adults (Table 3$)$. A similar age-related difference $(P<0.05)$ was observed in the Ngorongoro Crater population, and these values were not different $(P>0.05)$ from those measured in the lions of the Serengeti Plains. In contrast to LH receptors, FSH receptor concentrations were $\sim 50 \%$ lower $(P<0.05$ ) in adult and young adult compared to prepubertal males (Table 3). Concentrations were similar $(P>0.05)$ between young adult and adult males and were not affected by location $(P>0.05)$. Neither LH nor FSH binding was influenced $(P>0.05)$ by the pre-biopsy saline or GnRH treatment.

\section{Discussion}

These data agree with our earlier observations that semen characteristics vary between different geographic populations of free-ranging lions in the Serengeti ecosystem (Wildt et al., 1987). Adult lions of the Ngorongoro Crater consistently produced higher numbers of abnormal spermatozoa than did males of comparable age of the Serengeti Plains. However, an unexpected finding in 
Serengeti Plains lions was that age also affected semen quality. Young adult males produced only $60 \%$ of the number of structurally normal spermatozoa of their adult counterparts which was only about a $10 \%$ improvement over the values measured in the genetically-compromised males isolated in the Ngorongoro Crater. Post-pubertal increases in ejaculate volume, sperm concentration and motility (Killian \& Amann, 1972) and, in some cases, improvements in sperm morphology (Hanson et al., 1980) have been observed in the bull. In contrast, Chakraborty et al. (1989) reported normal sperm quality in the first pubertal ejaculates of the goat. It is surprising that the literature contains so little information on pubertal changes in semen quality, and the present results suggest that felids might be useful for further study. The impact of increased proportions of sperm abnormalities in lion ejaculates on sperm function and fertility is not known. However, Howard et al. (1989) recently demonstrated that spermatozoa from teratospermic domestic cats had a compromised ability to bind and penetrate homologous oocytes in vitro compared to normospermic males.

We had speculated that perhaps the poorer semen quality of Ngorongoro Crater lions was related to a compromised ability of the testis to secrete sufficient amounts of testosterone (Wildt $e t$ al., 1987), an important hormone for normal epididymal function and sperm maturation (Mann \& Lutwak-Mann, 1981). Indeed, this hypothesis is supported by evidence of a relationship between low circulating concentrations of testosterone and increased sperm abnormalities in other species (Bader et al., 1988) including felids (Wildt et al., 1984, 1987; Howard et al., 1990). In addition, our previous study suggested that mean circulating testosterone concentrations were lower in Ngorongoro Crater lions. However, these observations were based on a relatively small number of samples, and animals were not partitioned by age. In the present study, there were no apparent differences, within age class, in either basal or GnRH-stimulated testosterone secretion between the lions of the Serengeti Plains and Ngorongoro Crater. Instead, results of this study suggest that age was the major factor determining gonadal steroidogenic capacity. Both basal and GnRHstimulated testosterone secretion were considerably higher in adult than young adult lions for both populations. Maximal testosterone secretion in other species is usually achieved at the time of puberty or shortly thereafter (Ketelslegers et al., 1978; Lunstra et al., 1978; Chantaraprateep \& Thibier, 1979; Wilson \& Lapwood, 1979; Olster \& Foster, 1986). In the present study, despite the similarity in GnRH-induced LH release, sexually mature young males were unable to produce the marked rise in testosterone measured in their older, adult counterparts. In lions, therefore, there appears to be a more gradual increase in testicular sensitivity to LH with maximal testosterone secretion not occurring until $\sim 1-2$ years after puberty. In addition, while increased testosterone secretion was related to improved ejaculate quality in Serengeti Plains lions, this relationship did not exist for Ngorongoro Crater animals. Furthermore, there were no apparent alterations in pituitary-testicular function between the adult Serengeti Plains and Ngorongoro Crater lions that might account for these observed differences. We speculate that, although testosterone may play a role in the development of normal ejaculate quality in Plains lions, other mechanisms may be involved in controlling spermatogenic activity in Crater animals. For example, the reduced genetic variability observed in the Crater population may somehow interfere with normal sperm development, even in the presence of apparently normal concentrations of circulating testosterone. The majority of Serengeti (15 of 16; excluding prepubertal males) and Crater (10 of 12) lions were residents (i.e. breeding males) of well-established prides. Therefore, it appears that males with access to breeding females vary markedly in ejaculate characteristics, especially sperm motility and structural traits, and that these differences are associated closely with age. The impact of this finding on reproductive success will probably not be realized until paternity exclusion analyses, currently in progress, specifically identify which males are producing offspring.

Regarding GnRH-stimulated LH and testosterone secretion, 3 stages of sexual development were identified in the lion: (1) a prepubertal period characterized by increased pituitary sensitivity to GnRH coupled with low testicular sensitivity to endogenously released LH; (2) a transitional post-pubertal period in which pituitary sensitivity was reduced to adult levels, but testicular responsiveness was still diminished; and (3) an adult period of maximal testicular responsiveness 
associated with a pituitary sensitivity no different from that observed during the early post-pubertal period. In the present study, GnRH-stimulated LH release was more pronounced in prepubertal lions than in adult or young adult animals. Alterations in pituitary sensitivity during sexual maturation have been reported previously, but the pattern of change appears to be species-specific. For example, increased pituitary responsiveness during the prepubertal period, similar to that observed in the lion, has been observed in the rat (Debeljuk et al., 1972), bull (Chantaraprateep \& Thibier, 1979) and ram (Wilson \& Lapwood, 1979). In contrast, GnRH-stimulated LH release is minimal during the prepubertal period and then increases significantly at puberty in both the mouse (Jean-Faucher et al., 1985) and man (Garnier et al., 1974; Roth et al., 1972). Increased pituitary sensitivity in the prepubertal lion may be related to increased pituitary content of LH (Debeljuk et al., 1972; Chan et al., 1981) or concentrations of pituitary GnRH receptors (Chan et al., 1981; Dalkin et al., 1981) as described for the rat. Because testosterone is known to decrease pituitary GnRH receptor concentrations (Clayton \& Catt, 1981) and attenuate pituitary responsiveness to GnRH (Hopkinson et al., 1974), it is likely that the reduced GnRH-induced LH release observed in adult and young adult lions resulted from a direct negative-feedback action of the increased serum testosterone in these older animals. Compared to LH, the magnitude of the FSH response was not age-dependent and was similar to that described for other felids (Brown et al., 1988, 1989).

Basal testosterone secretion in adult and young adult lions declined significantly over time, without a corresponding change in LH secretion. A decline in testosterone over time has been observed consistently in the leopard (Brown et al., 1988, 1989; Wildt et al., 1988), but not in the tiger, puma or cheetah (Wildt et al., 1988), suggesting that the sensitivity to manipulations associated with handling and/or anaesthesia may be species-specific among felids. In this study, the age-related increases in testosterone secretion were positively associated with increases in the concentrations of testicular LH receptors, rather than to alterations in circulating LH concentrations. Changes in hCG-binding capacity of lion testis homogenates resemble those observed during development in the rat (Ketelslegers et al., 1978), except that in rats no further enhancement of LH receptor binding or testosterone secretion are observed after puberty. The increase in receptor binding is probably due to an increase in both Leydig cell size and numbers (Ketelslegers et al., 1978; Vandalem et al., 1986). The higher concentrations of testicular FSH receptors observed in prepubertal compared to adult lion testis agrees with reports for the rat (Ketelslegers et al., 1978), bull (Sundby et al., 1984) and boar (Vandalem et al., 1986) in which the increase in testicular FSH receptors precedes the initiation of spermatogenesis (Ketelslegers et al., 1978; Vandalem et al., 1986). This apparently is the case for the lion, since onset of spermatogenesis in this species normally occurs at $\sim 2$ years of age (Schaller, 1972).

We thank Dr Jerry Reeves for the gift of LH antiserum; Dr Jim Dias for the FSH antiserum; Dr Leo Reichert, Jr, for the iodination hormones and canine LH standard; NIADDK for all other hormone preparations; Dennis Gilbert for help with sample collection and handling; Sandy Hurlbut, Annette Mitchell and Myra Nelson for excellent technical assistance; Glenn Peterson and Charles Andres for help with the statistical analyses; and Jane Koeser for secretarial support. We also are grateful to Dr K. N. Hirji, Coordinator of the Serengeti Wildlife Research Institute, and the Government of Tanzania for their support. This study was supported, in part, by grants from The National Geographic Society, Friends of the National Zoo and National Science Foundation (No. 8507087).

\section{References}

Bader, H., Hoppen, H.O., Wockener, A. \& Merkt, H. (1988) Case studies in stallions with fertility problems: endocrine and spermatological aspects. Proc. 11 th Int. Cong. Anim. Reprod. \& AI, Dublin 3, 367, abstr.
Bertram, B.C.R. (1975) Social factors influencing reproduction in wild lions. J. Zool., Lond. 177, 463-482.

Brown, J.L. \& Chakraborty, P.K. (1988) Characterization of the effects of clomiphene citrate on reproductive 
physiology in male rats of various ages. Acta endocr., Copenh. 118, 437-443.

Brown, J.L., Goodrowe, K.L., Simmons, L.G., Armstrong, D.L. \& Wildt, D.E. (1988) Evaluation of the pituitarygonadal response to $\mathrm{GnRH}$, and adrenal status, in the leopard (Panthera pardus japonensis) and tiger (Panthera tigris). J. Reprod. Fert. 82, 227-236.

Brown, J.L., Wildt, D.E., Phillips, L.G., Seidensticker, J., Fernando, S.B.U., Miththapala, S. \& Goodrowe, K.L. (1989) Adrenal-pituitary-gonadal relationships and ejaculate characteristics in captive leopards (Panthera pardus kotiya) isolated on the island of Sri Lanka. J. Reprod. Fert. 85, 605-613.

Burke, T.J. (1986) Testicular biopsy. In Small Animal Reproduction and Infertility, a Clinical Approach to Diagnosis and Treatment, pp. 140-146. Ed. T. J. Burke. Lea \& Febiger, Philadelphia.

Bygott, J.D., Bertram, B.C.R. \& Hanby, J.P. (1979) Male lions in large coalitions gain reproductive advantages. Nature, Lond. 282, 839-841.

Chakraborty, P.K., Stuart, L.D. \& Brown, J.L. (1989) Puberty in the male Nubian goat: Serum concentrations of LH, FSH and testosterone from birth through puberty and semen characteristics at sexual maturity. Anim. Reprod. Sci. 20,91-101.

Chan, V., Clayton, R.N., Knox, G. \& Catt, K.J. (1981) Ontogeny of pituitary $\mathrm{GnRH}$ receptors in the rat. Endocrinology 108, 2086-2092.

Chantaraprateep, P. \& Thibier, M. (1979) LH and testosterone responses to gonadoliberin (LRH) treatment in young bulls prior to and during puberty. Annls Biol. anim. Biochim. Biophys. 19, 637-646.

Clayton, R.N. \& Catt, K.J. (1981) Regulation of pituitary gonadotropin-releasing hormone receptors by gonadal hormones. Endocrinology 108, 887-895.

Dalkin, A.C., Bourne, G.A., Pieper, D.R., Regiani, S. \& Marshall, J.C. (1981) Pituitary and gonadal gonadotropin-releasing hormone receptors during sexual maturation in the rat. Endocrinology 108, 1658-1664.

Debeljuk, L., Arimura, A. \& Schally, A.V. (1972) Studies on the pituitary responsiveness to luteinizing hormone-releasing hormone (LH-RH) in intact male rats of different ages. Endocrinology $90,585-588$.

Garnier, P.E., Chaussain, J.L., Binet, E., Schlumberger, A. \& Job, J.C. (1974) Effect of synthetic luteinizing hormone-releasing hormone ( $\mathrm{LH}-\mathrm{RH})$ on the release of gonadotrophins in children and adolescents. VI. Relations to age, sex and puberty. Acta endocr., Copenh. 77, 422-434.

Hanson, R.D., Mitchell, J.R. \& Fleming, W.N. (1980). Abnormal sperm cell patterns in young Holstein sires. J. Anim. Sci. 51 (Suppl. 1), 282, abstr.

Harrison, R.M., Dominique, G.J., Heidger, P.M., Roberts, J.A. \& Schlegel, J.U. (1977) Vasectomy in the rhesus monkey. I. Surgical techniques and gross observations. Urology 9, 639-644.

Harvey, W.R. (1988) Users Guide for LSMLMW, PC-1 Version. The Ohio State University, Columbus, $\mathrm{OH}$.

Hopkinson, C.R.N., Pant, H.C. \& Fitzpatrick, R.J. (1974) Release of LH and FSH in the normal intact ram by synthetic LH-RF and the effect of pretreatment with testosterone propionate. J. Reprod. Fert. 39, 135-139.

Howard, J.G., Hurlbut, S.L. \& Wildt, D.E. (1989) Compromised zona binding and penetration of hom- ologous oocytes by spermatozoa from teratospermic domestic cats. Biol. Reprod. 40 (Suppl. 1), 161, abstr.

Howard, J.G., Brown, J.L., Bush, M. \& Wildt, D. (1990) Teratospermic and normospermic domestic cats: Ejaculate traits, pituitary-gonadal hormones and improvement of spermatozoal viability and morphology after swim-up processing. $J$. Androl. 11, 204 215.

Jean-Faucher, C., Watik, N.E., Berger, M., de Turckheim, M., Veyssiere, G. \& Jean, C. (1985) Regulation of gonadotropin secretion in male mice from birth to adulthood. Response to LRH injection, castration and testosterone replacement therapy. Acta endocr., Copenh. 110, 193-199.

Ketelslegers, J.M., Hetzel, W.D., Sherins, R.J. \& Catt, K.J. (1978) Developmental changes in testicular gonadotropin receptors: plasma gonadotropins and plasma testosterone in the rat. Endocrinology 103, 212-222.

Killian, G.J. \& Amann, R.P. (1972) Reproductive capacity of dairy bulls. IX. Changes in reproductive organ weights and semen characteristics of Holstein bulls during the first thirty weeks after puberty. $J$. Dairy Sci. 55, 1631-1635.

Lunstra, D.D., Ford, J.J. \& Echternkamp, S.E. (1978) Puberty of beef bulls: hormone concentrations, growth, testicular development, sperm production and sexual aggressiveness in bulls of different breeds. J. Anim. Sci. 46, 1054-1062.

Mann, T. \& Lutwak-Mann, C. (1981) Testis and testicular semen. In Male Reproductive Function and Semen, pp. 83-138. Springer-Verlag, New York.

O'Brien, S.J., Martenson, J.S., Packer, C., Herbst, L., de Vos, V., Joslin, P., Ott-Joslin, J., Wildt, D.E. \& Bush, M. (1987) Biochemical genetic variation in geographic isolates of African and Asiatic lions. Natn. Geog. Res. 3, 114-124.

Olster, D.H. \& Foster, D.L. (1986) Control of gonadotropin secretion in the male during puberty: A decrease in response to steroid inhibitory feedback in the absence of an increase in steroid-independent drive in the sheep. Endocrinology 118, 2225-2234.

Packer, C., Herbst, L., Pusey, A.E., Bygott, J.D., Hanby, J.P, Cairns, S.J. \& Bergerhoff-Mulder, M. (1988) Reproductive success of lions. In Reproductive Success, pp. 363-383. Ed. T. H. Clutton-Brock. University of Chicago Press, Chicago.

Pennycuick, C. \& Rudnai, J.A. (1970) A method of identifying individual lions, Panthera leo, with an analysis of the reliability of the identification. J. Zool., Lond. 160, 497-508.

Pusey, A.E. \& Packer, C. (1987) The evolution of sexbiased dispersal in lions. Behaviour 101, 275-310.

Roth, J.C., Kelch, R.P., Kaplan, S.L. \& Grumbach, M.M. (1972) FSH and LH response to luteinizing hormonereleasing factor in prepubertal and pubertal children, adult males and patients with hypogonadotropic and hypergonadotropic hypogonadism. J. clin. Endocr. Metab. 35, 926-930.

Schaller, G.B. (1972) In The Serengeti Lion: a Study of Predator-Prey Relations. University of Chicago Press, Chicago.

Sundby, A., Andersen, D., Purvis, K. \& Hansson, V. (1984) Testicular gonadotropin receptors, testicular 
testosterone, dihydrotestosterone and androstenedione in the developing bull. Archs Androl. 12, 59-64.

Vandalem, J.L., McNamara, M., Petit, R. \& Hennen, G. (1986) Developmental changes in gonadotrophins and testicular gonadotrophin receptors in the pig from neonatal to adult life. $J$. Endocr. 111, 301-308.

Wildt, D.E., Bush, M., Howard, J.G., O'Brien, S.J., Meltzer, D., van Dyk, A., Ebedes, H. \& Brand, D.J. (1983) Unique seminal quality in the South African cheetah and a comparative evaluation in the domestic cat. Biol. Reprod. 29, 1019-1025.

Wildt, D.E., Meltzer, D., Chakraborty, P.K. \& Bush, M. (1984) Adrenal-testicular-pituitary relationships in the cheetah subjected to anesthesia/electroejaculation. Biol. Reprod. 30, 665-672.
Wildt, D.E., Bush, M., Goodrowe, K.L., Packer, C. Pusey, A.E., Brown, J.L., Joslin, P. \& O'Brien, S.J. (1987) Reproductive and genetic consequences of founding isolated lion populations. Nature, Lond. 329, 328-331.

Wildt, D.E., Phillips, L.G., Simmons, L.G., Chakraborty, P.K., Brown, J.L., Howard, J.G., Teare, A. \& Bush, M. (1988) A comparative analysis of ejaculate and hormonal characteristics of the captive male cheetah, tiger, leopard and puma. Biol. Reprod. 38, 245-255.

Wilson, P.R. \& Lapwood, K.R. (1979) Studies of reproductive development in Romney rams. I. Basal levels and plasma profiles of $\mathrm{LH}$, testosterone and prolactin. Biol. Reprod. 20, 965-970.

Received 29 January 1990 